\title{
Abstract not submitted at time of publication
}

\author{
Clinical and Translational Allergy 2045-7022 20111 Suppl 1 S15
}

Published: 12 August 2011

doi:10.1186/2045-7022-1-S1-S15

Cite this article as: : Abstract not submitted at time of publication.

Clinical and Translational Allergy 2011 1(Suppl 1):S15

Submit your next manuscript to BioMed Central and take full advantage of:

- Convenient online submission

- Thorough peer review

- No space constraints or color figure charges

- Immediate publication on acceptance

- Inclusion in PubMed, CAS, Scopus and Google Scholar

- Research which is freely available for redistribution

Submit your manuscript at www.biomedcentral.com/submit

\section{() Biomed Central}

